\title{
47. SEDIMENTS RECOVERED FROM THE NORTHWEST AFRICAN CONTINENTAL MARGIN, LEG 41, DEEP SEA DRILLING PROJECT
}

\author{
J.V. Gardner, U.S. Geological Survey, Menlo Park, California, \\ W.E. Dean, U.S. Geological Survey, Denver, Colorado, \\ and \\ L. Jansa, Geological Survey of Canada, Dartmouth, Nova Scotia, Canada,
}

\section{INTRODUCTION}

The sediments cored on Leg 41 (Figure 1) provide many clues regarding a number of general problems in deep-sea sedimentology. These include the nature and origin of cyclic sequences, progressive and regressive diagenesis with depth, and the origin of deep-sea barite. In addition, they provide insight into some regional stratigraphic problems, such as the nature of acoustic reflectors, the origin of the widespread Cretaceous black shales, the distribution of volcanic materials and timing of volcanism associated with the building of the Canary and Cape Verde islands, and the regional correlation of Upper Jurassic and Lower Cretaceous sediments of the early Atlantic and Tethyan Mediterranean. Leg 41 sediments provided a number of surprises, and raised many questions, many of which are still unanswered.

We expected to find carbonate sediments comprising a pelagic facies deposited above the CCD at the two rise sites (Site 366, Sierra Leone Rise, and Site 368, Cape Verde Rise). We found a remarkably complete low latitude pelagic-carbonate section of the entire Cenozoic on the Sierra Leone Rise (Site 366). This site apparently has been a prominent topographic rise since at least the Cretaceous, receiving biogenic pelagiccarbonate sediments with very little terrigenous contamination. However, at Cape Verde Rise only the post-middle Miocene section contained pelagiccarbonate sediments, and even these have considerable admixtures of terrigenous clastics. The rest of the section at Site 368 (middle Miocene to Lower Cretaceous) is hemipelagic and consists mainly of turbidites. Events recorded in the section at Site 368 show that the Cape Verde Rise became a positive topographic feature by post-early Miocene uplift of at least 1000 meters, related to the early Neogene volcanic activity that created the Cape Verde Islands.

We expected, and found, noncarbonate pelagic sediments at the basin sites (Site 367, Cape Verde Basin, and Site 370, deep basin off Morocco) admixed with abundant terrigenous material from the nearby African continent. However, at Site 370 we were not prepared for such a thick section of clastic and hemapelagic sediments, especially the numerous coarse sand and gravel beds. Most of the section at Site 370 represents submarine fan deposits, which contain more than 1000 meters of monotonous turbidites ranging in age from Early Cretaceous to middle Miocene. There is a hiatus

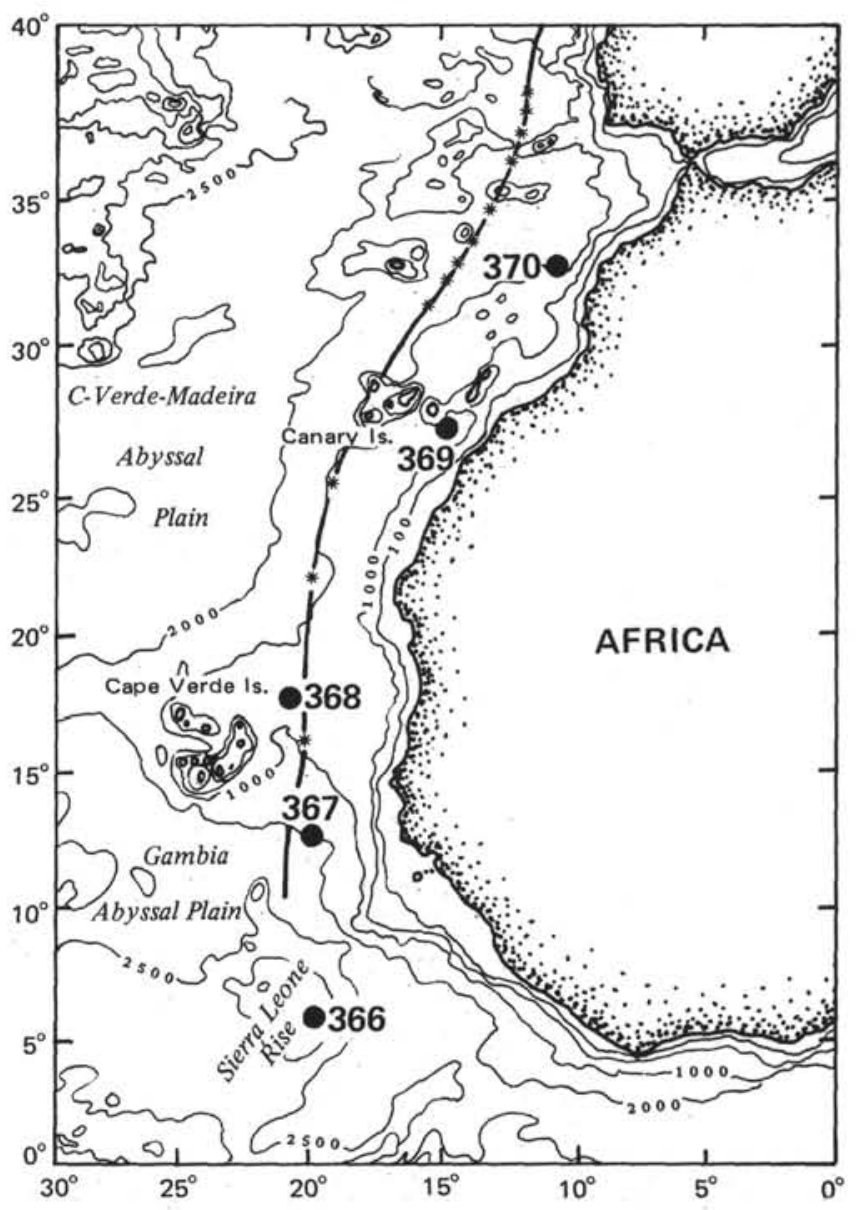

Figure 1. Location of Sites drilled on Leg 41, DSDP. Starred line represents location of the magnetic quiet zone (after Rabinowitz and Hayes, 1975).

of about $35 \mathrm{~m} . y$. within this cyclic sequence, with very little difference in character of the sediments above and below the unconformity (Figure 2). We also found a thick sequence of cyclic sediments at Site 367 in the Cape Verde Basin but these are mainly organic-rich to organic-poor cycles that reflect pulses of organic debris and other terrigenous components from the African continent. The most impressive aspect of the section at Site 367 is the remarkable similarity of the Mesozoic sediments to those cored in the North American Basin (Leg 11, Sites 99, 100,101, and 105), and the classic sequences of the Tethyan Mesozoic. 


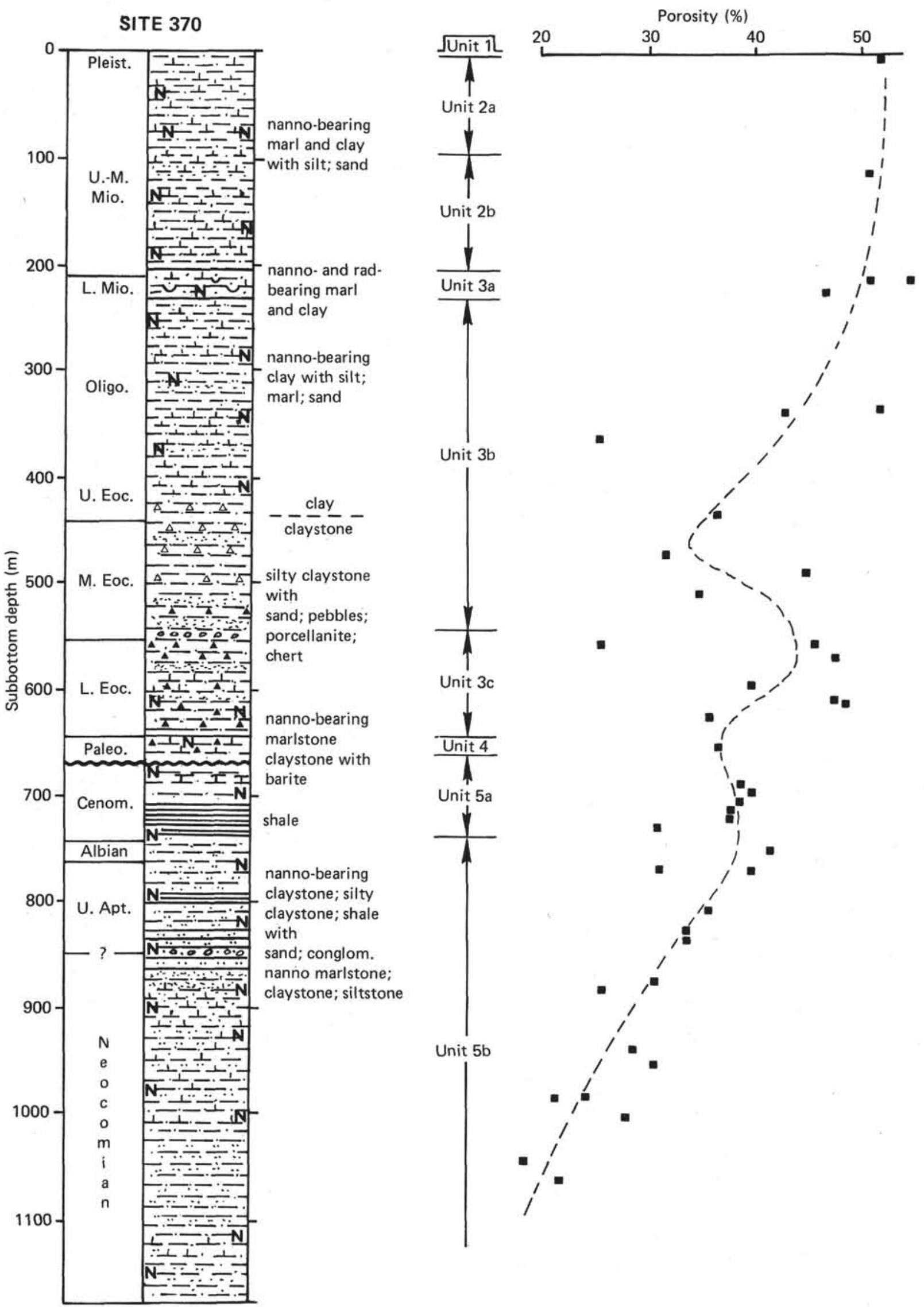

Figure 2. Stratigraphy, lithology, and porosity for Site 370. 
At Site 369 on the continental slope off Spanish Sahara we expected to find a hemipelagic sequence dominated by terrigenous components. Instead, we found a dominant biogenic-carbonate pelagic section with only minor terrigenous admixtures. We were surprised not to find terrigenous components which are so abundant at Sites 367,368 , and 370 , and which should be abundant on the continental slope. We also expected to find a Lower Cretaceous shallow-water limestone, based on correlation of acoustic reflectors with known stratigraphy of the Spanish Saharan continental shelf. However, no evidence of shallowwater deposition was found at this site.

We anticipated a remote possibility of encountering Jurassic evaporites at Site 369 and 370 . Although no evaporites were encountered, we did find marked increases in salinities of interstitial water at these two sites. Similar increases in salinity in sediments in the Angola Basin (Sites 364 and 365) led the Leg 40 scientists to conclude that the evaporites were just a few tens of meters away (Bolli, Ryan, et al., 1975). The early Mesozoic evaporites of the early Atlantic Ocean continue to elude the drill string of Glomar Challenger.

\section{CYCLIC SEDIMENTATION}

Long sequences of cyclic sediments were cored during Leg 41 . Three main types of cycles were recognized: (1) fluctuations in supply of terrigenous components; (2) diagenesis, due mainly to fluctuations in (a) $p \mathrm{H}$ and Eh (redox) in the sediments and possibly bottom waters, (b) dissolution and reprecipitation of $\mathrm{CaCO}_{3}$, and (c) dissolution and reprecipitation of $\mathrm{SiO}_{2}$; and (3) fluctuations in dissolutions of $\mathrm{CaCO}_{3}$. The nature and origin of these cycles are discussed in detail in Dean et al., (this volume).

Silt-clay turbidite cycles are particularly well developed in the Eocene and Paleocene sediments at Site 368 on the Cape Verde Rise, but are also present in deep-basin sediments at Site 367 off Senegal and Site 370 off Morocco. Turbidites, where well developed and when sufficient biostratigraphic time control exists, exhibit periods of the order of $10^{4} \mathrm{yr}$.

The most common redox cycles are recorded as striking color changes related to organic-rich and organic-poor sediments. These cycles include sharp interbeds of black and green clay or shale, red and green clay or shale, and white and black limestone and marlstone, all with periods on the order of 50,000 yr. Other evidence of diagenetic cycles are the striking red and light green nodular limestones of Late Jurassic age in the Cape Verde Basin and $\mathrm{SiO}_{2}$ replacement common at most sites.

Inferred cycles of carbonate dissolution are particularly well developed in upper Eocene to middle Miocene carbonate sediments on the Sierra Leone Rise (Site 366). These cycles are alternations of chalk and clay, or nanno ooze and marl on a scale of 40 to $70 \mathrm{~cm}$, representing cycle periods of the order of 30,000 to $50,000 \mathrm{yr}$.

We believe the redox and carbonate-dissolution cycles were controlled by long-term climatic fluctuations. The dissolution cycles have a period of 30,000 to $50,000 \mathrm{yr}$. with an average of about $45,000 \mathrm{yr}$.
Redox cycles have similar periodicities. These cycle periods match the orbital periodicity used by Milankovitch (1938), Broecker and von Donk (1970), and others to explain the forcing function of climatic change. Many studies of Pleistocene deep-sea sediments have found cycles with this periodicity and we think it is reasonable to extend this concept of climatic-induced cycles through the Neogene and possibly into the Paleogene.

The turbidites occur with periods ranging from 7000 to $21,000 \mathrm{yr}$., but we do not contend that their deposition is necessarily controlled by climatic fluctuations alone. Because slope instability and the processes that trigger turbidity currents act at a more random frequency than do climatic fluctuations, the two processes are superimposed one upon the other.

We interpret the redox cycles to be the result of pulsed organic input that caused fluctuations in anoxic conditions within the sediments, thereby allowing greater preservation of organic matter. The sedimentary record in the Cape Verde Basin (Site 367) indicates that the pulsing of organic matter began there at least as early as Late Jurassic and continued at least through the Eocene. The carbonate-dissolution cycles may represent dilution by clay in a dominant carbonate pelagic sequence, but observations of sediment composition, clay mineralogy, and abundance and preservation of nannofossils all suggest that the cycles are the result of periodic fluctuations in degree of $\mathrm{CaCO}_{3}$ dissolution, at times aided by clastic dilution.

\section{PROGRESSIVE DIAGENESIS WITH DEPTH}

The sediments cored on Leg 41 provide many excellent examples of progressive and regressive diagenesis with increasing depth within a core. Normally, one would expect diagenetic changes to increase (progress) with burial, and in general, this is usually true. For example, calcareous ooze usually changes to chalk, which changes to limestone with increasing depth. However, results of deep-sea drilling have provided numerous examples of reversals in diagenesis with depth. For example, chalk has been found sandwiched between two limestone units that appear to have the same composition as the chalk except that they are cemented and the chalk is not. Initial porosity and permeability undoubtedly play a large role in diagenesis and lithification, but other factors are involved. For example, Schlanger and Douglas (1974) conclude that the propensity of a sediment to undergo diagenesis (what they termed "diagenetic potential") is a function of water depth, sedimentation rate, surface organic productivity, grain size, and amount and type of fossil remains. They observed that progressive diagenesis of a carbonate section from ooze to chalk to limestone is accompanied by marked changes in calcareous fossil remains. Foraminifers decrease rapidly in absolute abundance, and become more fragmented; nannofossils change in relative abundance with a decrease in the more easily dissolved coccoliths, and a relative increase in the more dissolution-resistant discoasters. Schlanger and Douglas observed an overall decrease in porosity with 
depth, but also noted that this trend is apparently reversible, with small-scale fluctuations in porosity on a centimeter to decimeter scale.

The carbonate section at Site 366 is an excellent example of overall progressive diagenesis and resultant lithification with depth, but with reversals on several scales. Figure 3 shows a close correlation between lithologic change and physical properties at this site. Physical properties at the top of the section vary mainly with clay content. The first chalk occurs in Core $18 \mathrm{~A}$ (ca. $165 \mathrm{~m}$; lower Miocene) and caused a sharp decrease in drilling rate. There is a general increase in clay content accompanied by a decline in porosity between 350 and 450 meters (Oligocene to upper Eocene). Porcellanite first occurs at $\mathbf{4 9 0}$ meters (middle Eocene) accompanied by noticeable calcite recrystallization and a decline in the abundance of nannofossils. Increased cementation by both $\mathrm{SiO}_{2}$ and $\mathrm{CaCO}_{3}$ resulted in a marked decrease in porosity, an increase in sonic velocity, and a much lower drilling rate. The horizon at about 400 meters correlates with a strong acoustic reflector (see Site 366 Summary Chapter).

Cementation of some chalk beds into limestone occurs at about 530 meters (middle Eocene), the level where cycles of chalk, chert, and limestone first appear (see Dean et al., this volume). Here, fluctuations in degree of cementation occur on a scale of 5 to $10 \mathrm{~cm}$. A typical $20-\mathrm{cm}$ thick cycle consists of about $8 \mathrm{~cm}$ of chalk overlain by about $8 \mathrm{~cm}$ of limestone which in turn is overlain by about $4 \mathrm{~cm}$ of chert. The only apparent difference between the chalk and the limestone is a greater clay content of the chalk, which suggests that a higher initial clay content resulted in lower initial porosity and consequent lower rate of cementation.

By about 590 meters (middle-lower Eocene boundary), even clay-rich units have been cemented so that the lithology is interbedded siliceous and argillaceous limestones. There is a marked decrease in amount of $\mathrm{CaCO}_{3}$ (increase in clay) at this point. By 590 meters the section consists of approximately half siliceous limestone and half argillaceous limestone in interbeds about $10 \mathrm{~cm}$ thick. Clay content increases with depth and, by 680 meters, the lithology is dominantly one of argillaceous limestone. As a result of lower depositional permeabilities, the clays and marls are now less cemented and have higher porosities and lower sonic velocities than do the more calcareous sediments. The argillaceous limestone is not as well cemented and is softer than the siliceous limestone. This is clearly seen by an increase in drilling rate and a decrease in sonic velocity on Figure 3. In other words, those original calcareous oozes with higher clay contents had lower diagenetic potentials (in the sense of Schlanger and Douglas, 1974) and have therefore undergone less diagenetic reduction in porosity. These differences in degree of diagenesis occur on scales of decimeters, meters, and hundreds of meters.

Cementation of $\mathrm{SiO}_{2}$ and $\mathrm{CaCO}_{3}$ again increase at about 730 meters (lower Eocene-upper Paleocene boundary) with a resultant decrease in porosity and drilling rate, and an increase in sonic velocity.

A reversal of diagenesis in a carbonate section was observed at Site 369, where the lithostratigraphic sequence consists of argillaceous limestone cemented with both $\mathrm{SiO}_{2}$ and $\mathrm{CaCO}_{3}$ sandwiched between marls and argillaceous chalks (Figure 4). Cementation of marl into argillaceous limestone first occurs about 350 meters (middle Eocene) and continues to about 384 meters. Chert and porcellanite first appear at about 367 meters as nodules in argillaceous limestone and continue through about 410 meters as nodules in nannofossil marl. The contact between $\mathrm{CaCO}_{3-}$ and $\mathrm{SiO}_{2}$-cemented argillaceous limestone and overlying soft marl corresponds to the prominent acoustic reflector, D1 (see Site Chapter 369). The marls below the limestone contain numerous thin interbeds of argillaceous limestone associated with the occurrence of barite (or calcite pseudomorphous after barite; Figure 2) (see Dean and Schreiber, this volume). Calcite cementation at Site 369 and the formation of the barite appear to be related to the presence of a major unconformity and an increase in interstitial salinity (see Dean and Schreiber, this volume). The higher lithification of the carbonate around the unconformity suggests a similar diagenetic process which leads to the development of "hardground."

Another case of $\mathrm{CaCO}_{3}$ cementation, related to primarily permeability (Figure 2), occurs within turbidites at Site 370 . There is little primary biogenic calcite in the turbidites, but there is a considerable amount of secondary calcite cementation of coarser beds. Most of this secondary sparry calcite is iron rich (see Jansa et al., this volume) and represents late diagenetic and epigenetic cement. Selective cementation of coarse layers, particularly in the Lower Cretaceous at Site 370 , is undoubtedly related to better interstitialwater circulation in the more permeable beds and laminae than in fine-grained lithologies, and to inorganic precipitation of the carbonate. Diagenetic changes occur in clastic sediments at Site 367 and 368 which are overlain by Neogene carbonate sections. The marls of lithologic Unit 1 at Site 367 (Figure 5) show no obvious diagenetic features and compaction is minimal. Unit 2 shows signs of compaction and incipient carbonate precipitation, as indicated by overgrowths on nannofossils and the presence of carbonate rhombs of undetermined mineralogy.

Chert and porcellanite first occur at Site 367 in the middle Miocene zeolitic clay at about 332 meters. This horizon correlates with the only distinct seismic reflector observed at Site 367 and is equivalent to acoustic Horizon A, so prominent in most seismic reflection profiles in the Atlantic. The presence of chert at Site 367 appears closely related to the presence of radiolarians and diatoms. Radiolarians are rare in Unit 2 (Pleistocene to middle Miocene), and no chert is present. Radiolarians and diatoms become very common to dominant in the sediments at the top of Unit 2 (late Eocene), and the first chert occurs 30 meters below this horizon. Contacts between porcellanite and chert are transitional; chert is commonly enveloped by porcellanite which in turn has gradational contacts with the surrounding sediments. Porcellanite and chert are generally bounded on one side by a less-permeable bed of clay or marl, suggesting that permeability controlled the diagenetic remobiliza- 


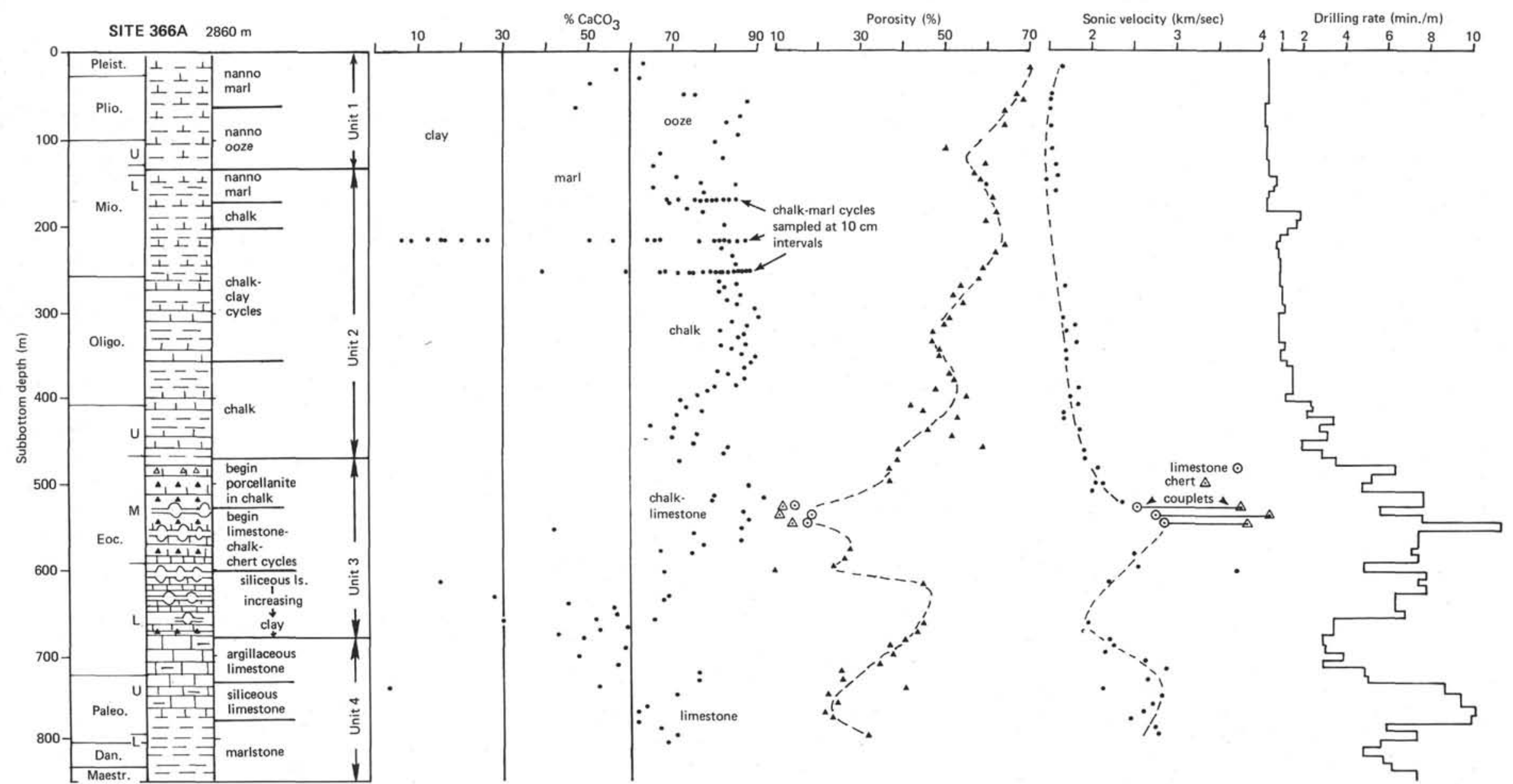

Figure 3. Stratigraphy, lithology, carbonate content, porosity, sonic velocity, and drilling rates for Site 366. 

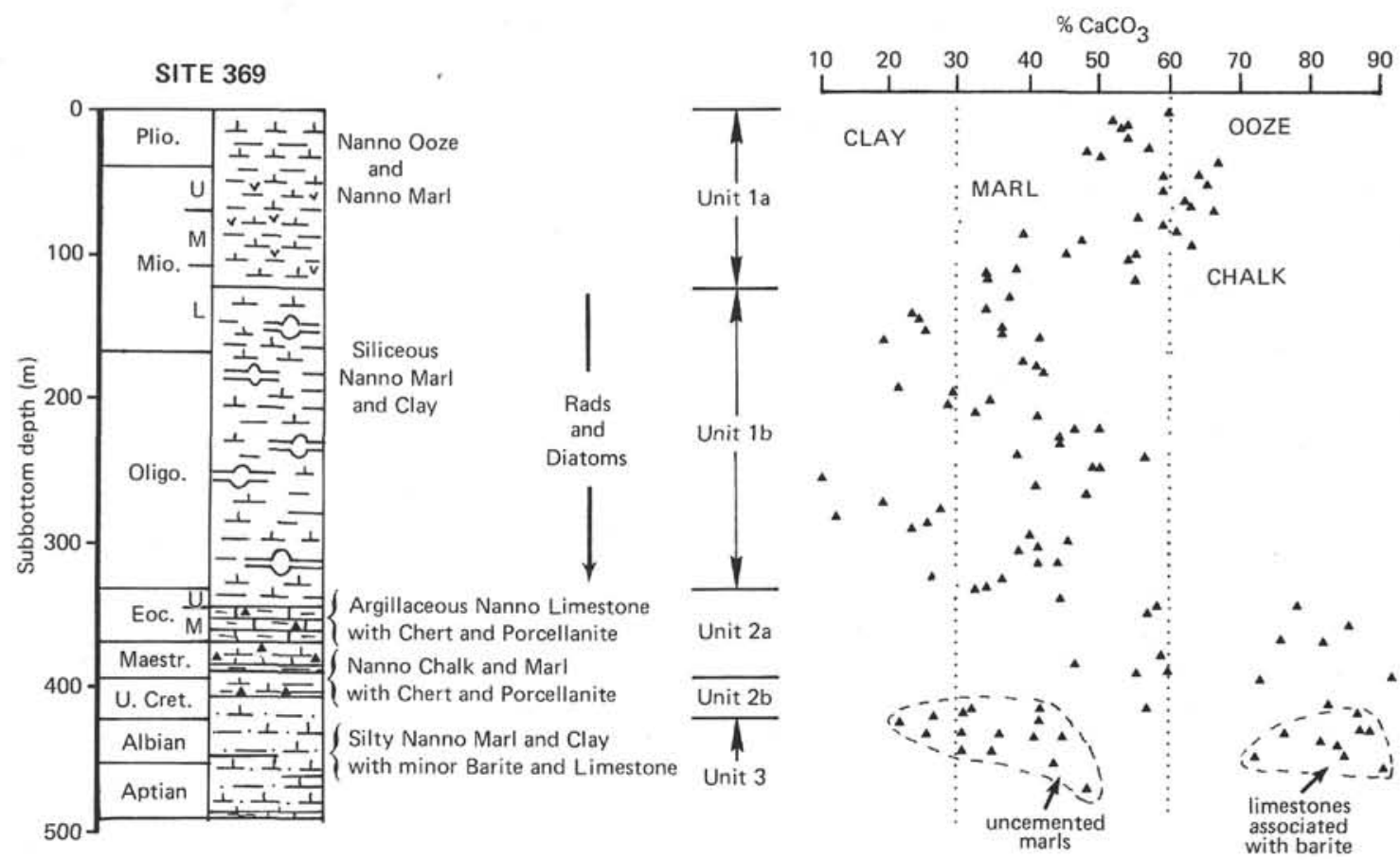

Figure 4. Stratigraphy, lithology, and carbonate content for Site 369.

tion of $\mathrm{SiO}_{2}$. The porcellanite in those porcellanitechert couplets studied was composed of isolated "spherules" of cristobalite, and chert was composed of microcrystalline quartz. Chert becomes rare in the upper part of Unit 3 (Paleocene), and then occurs again in the limestone sections of Neocomian (Unit 5) and Late Jurassic (Unit 6) ages. Radiolarians are frequent in both of these units but they occur mostly as calcitereplaced casts. Here again, permeability seems to have controlled silicification because chert is always found just above a red argillaceous unit. For additional details of the occurrence of chert and porcellanite in these sediments, see von Rad (this volume).

Clay-rich units show an overall linear decrease in porosity with depth beginning in Unit 2 at Site 367 (Figure 5). The zeolitic clays of Unit 2, though very stiff, are not very well compacted and have porosities $>60 \%$. The firm, subfissile silty clay of Unit 3 (porosity ca. $50 \%$ ) represents a transition between the lessindurated clay of Unit 2 and the hard fissile shale of Unit $4 \mathrm{a}$ (porosities $40 \%$ to $47 \%$ ). The interbedded black shale and green clay in Core 17 (540 to $549.5 \mathrm{~m})$ represent a transition between Unit 3 and Unit $4 \mathrm{a}$. The Lower Cretaceous red and green clay (Unit $4 \mathrm{~b}$ ) below the black shale unit have porosities about the same as the black shale. The Lower Cretaceous and Jurassic limestones of Units 5 and 6 all have porosities of between $5 \%$ and $28 \%$.

The first evidence of carbonate cementation at Site 367 is found in Unit 5 where some limestones are very well cemented and nannofossils are completely replaced by microsparite. Finally, stylolites, indicating dissolution of some limestone by compaction, first occur in Unit 5b (Core 31) and are especially common in Unit 6.

The top 200 meters of the section at Site 368 consists of calcareous ooze that shows no diagenetic effects other than slight decrease in porosity due to compaction (Figure 6). The content of $\mathrm{CaCO}_{3}$ declines rapidly below about 180 meters and calcareous fossils decrease in abundance and degree of preservation. However, these changes are probably not caused by diagenetic carbonate dissolution but rather by increased degree of $\mathrm{CaCO}_{3}$ preservation as the site was uplifted above the CCD beginning in post-early Miocene (see Site 368 Summary Chapter, this volume). The section below 200 meters consists mainly of clay that shows a general decrease in porosity due to increased compaction with depth. Higher porosities at about 250 meters are produced by the presence of volcanic ash in individual layers and disseminated throughout the clay. Clay has been compacted into claystone by 322 meters, yet the sediments are overpressured (see Site 368, physical properties) as seen by the cores actually expanding beyond the $150-\mathrm{cm}$ sections cut. This undercompacted nature is also reflected in the increased porosities seen in Figure 6 between 300 and 375 meters. Coarse detrital minerals, mainly subangular quartz, are common within lithologic Subunit 2a (below ca. $265 \mathrm{~m}$ ) and are especially common below about 450 meters. The coarse clastics are disseminated within the claystone, but also occur as laminae and thin beds. These clastics may be responsible for the increased porosities between 400 and 600 meters (Figure 6), even though the clays and claystones show a general trend of increasing induration with depth. This increased porosity may also explain why the Eocene section containing porcellanite and chert is unusually thick at Site 368 .

Layers and nodules of porcellanite first occur at Site 368 at about 350 meters and continue to a depth of about 625 meters. Chert is rare compared with other Eocene chert-porcellanite sections and occurs mainly as small nodules. The top of the siliceous section does not 


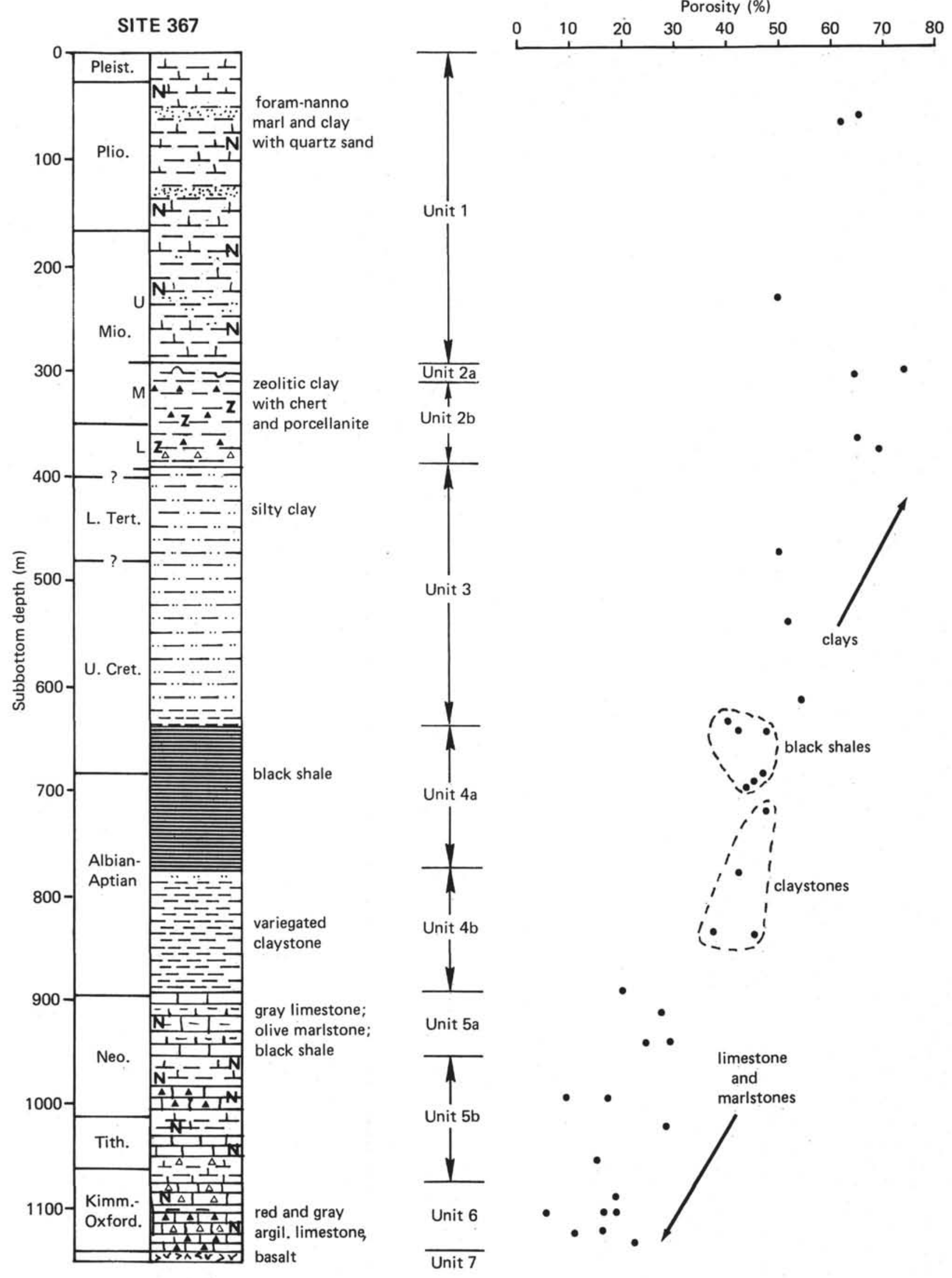

Figure 5. Stratigraphy, lithology, and porosity for Site 367. 

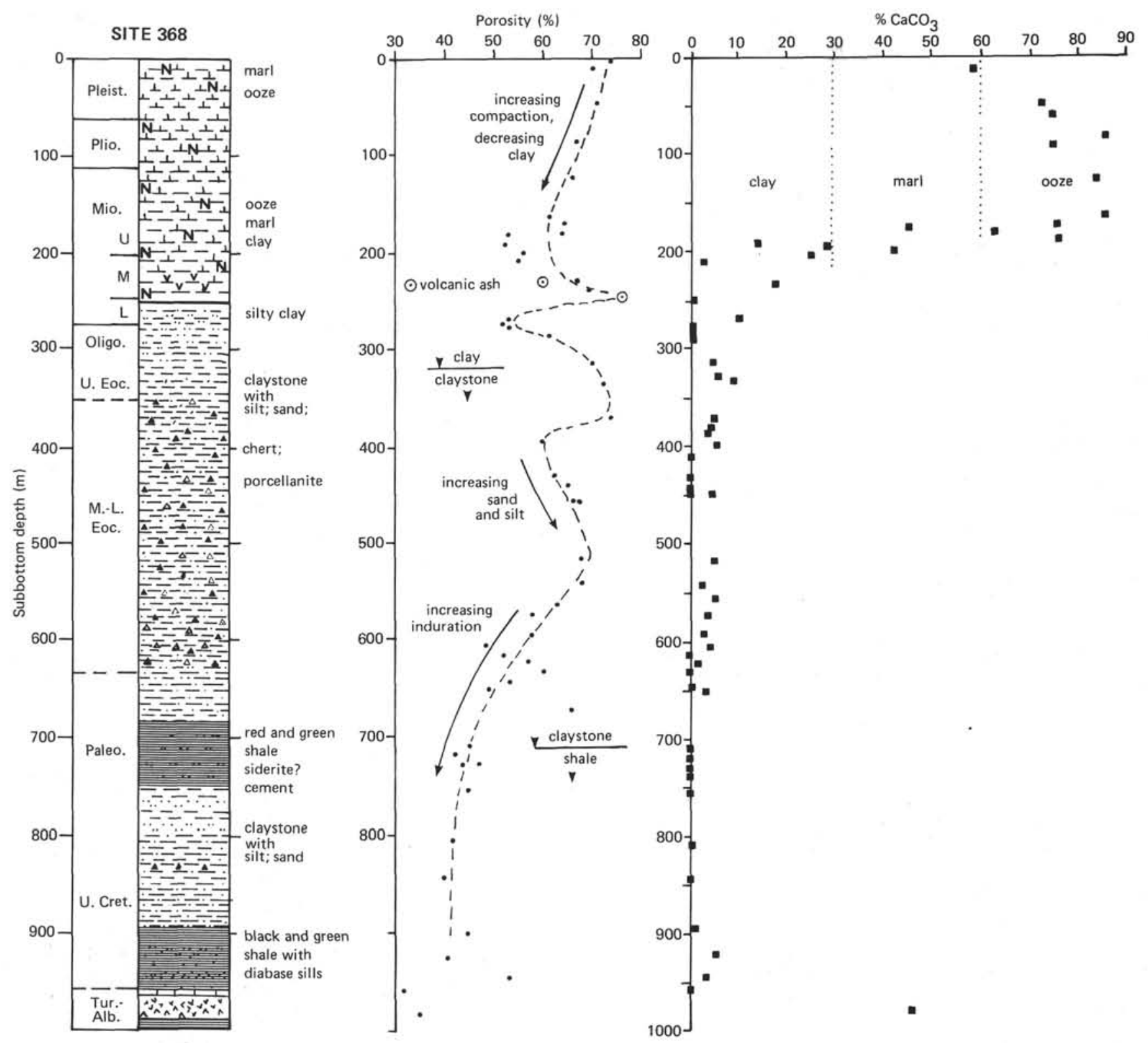

Figure 6. Stratigraphy, lithology, porosity, and carbonate content from Site 368.

produce a sharp acoustic reflector at Site 368, as it does at most other localities in the Atlantic, probably because of the low relative abundance of chert and porcellanite in this section. Porcellanite normally occurs within the darker lower member of the (darklight) claystone-turbidite couplets characteristic of lithologic Subunit 2a at Site 368. Porcellanite occurs as distinct dark greenish gray layers in Core $23(351 \mathrm{~m})$ with lighter colored silicified zones on either side. Below about 450 meters, claystones are darker, harder, and siltier, and porcellanite may be found anywhere within a turbidite unit but generally occurs at the base. Porcellanite rarely occurs in the upper lighter colored clay member of a turbidite couplet.

Below about 550 meters, coarse clastics and chert and porcellanite decrease in abundance and claystone becomes increasingly more indurated with a resultant constant decrease in porosity with depth (Figure 6)
Compaction of the claystone is aided by carbonate cementation below 625 meters. Clay first becomes fissile at a depth of about 700 meters, but welldeveloped shale is not the dominant lithology until the base of lithologic Subunit $2 \mathrm{c}$ and Unit 3. These Cretaceous shales have the same porosities (ca. $40 \%$ ) as the Cretaceous shales at Site 367. Thermal alteration of the Cretaceous shales by intrusions of early Miocene diabase sills at the base of the section cored at Site 368 has not significantly affected the physical properties of the shale.

\section{BARITE, UNCONFORMITIES, EVAPORITES, AND ORGANIC MATTER}

Rosettes, lenses, and laminae of barite, or calcite pseudomorphs after barite, are common in highly organic Lower Cretaceous sediments at Sites 369 and 370. Details of these occurrences are discussed by Dean 
and Schreiber (this volume). The barite occurs below major unconformities at both sites and is associated with marked increases in interstitial water salinities and calcite cementation. Surprisingly, the unconformities are not reflected by marked changes in facies. These associations suggest several important conclusions regarding the origin of barite at Sites 369 and 370, and of deep-sea barite in general. The barite formed diagenetically under oxidizing or slightly reducing conditions in sediments exposed at the sediment-water interface for long periods of time during pauses in accumulation. The main source of barium was from oxidation of organic material. The association of the barite with unconformities, high interstitial water salinities, and abundant pyrite suggests three possible sources of sulfate: (1) downward diffusion of sea water sulfate into the sediments during hiatuses to replace sulfate consumed by barite formation and bacterial sulfate reduction; (2) upward diffusion of sulfate from dissolution of Jurassic evaporites that are suspected to underlie both sites; and (3) oxidation of pyrite.

A survey of reports of deep-sea barite in surface sediments and in other Deep Sea Drilling Project cores reveals that barite occurs in every type and age of sediment, and is most abundant in highly organic sediments. Unlike the large rosettes found at Sites 369 and 370 , most deep-sea barite is fine grained ( 2 to 20 $\mu \mathrm{m})$.

\section{LOWER CRETACEOUS "BLACK SHALE"}

Organic-rich sediments of Aptian to Cenomanian age were cored at Sites 367, 368, 369 and 370. The character of the sediments changes somewhat between sites, and in general organic content decreases from south to north along the African continental margin. Lithologic Unit 4A at Site 367 consists of interbedded gray-green clay and black shale (Figure 7). The black shale commonly has organic-carbon concentrations greater than $10 \%$, and one sample contained $28 \%$ organic carbon. At Site 368, Cretaceous black shales have been intruded by early Miocene diabase sills (Figure 6). Concentrations of organic carbon in these shales $(1.0 \%$ to $7.5 \%$ ) are less than those in the black shale at Site 367. The Aptian to Cenomanian section at Site 369 consists not of black shale but of marl with concentrations of organic carbon generally around $1 \%$, but as high as $6.4 \%$. In contrast, the overlying Upper Cretaceous marl contains only $0.1 \%$ to $0.2 \%$ organic carbon. At Site 370. most of the Cretaceous section above lower Cenomanian is missing. The Aptian to lower Cenomanian section consists of clay, claystone, and shale, highly variable in character and ranging in color from dark greenish gray to olive-black. Palynomorphs and plant fragments are rare to common throughout the section. Concentrations of organic carbon are generally between $0.6 \%$ and $1 \%$, but may be as high as $4.8 \%$.

The Aptian to Cenomanian sections at Sites 369 and 370 do not contain what might be described as black shale, but they clearly contain abundant organic material reflecting higher than normal organic input. Organic material was diluted by pelagic carbonates at Site 369 and by rapid accumulation of terrigenous material at Site 370 .
Highly organic sediments of Early Cretaceous age have been cored at several other sites in the eastern Atlantic (Sites 135, 137, 138, 361, and 364), and at a number of sites in the western Atlantic (Sites 101, 105, 144,386 , and 387). Most of these sediments contain concentrations of organic carbon around $1 \%$ to $2 \%$ although considerably higher local concentrations are common. In general terms, these sediments are usually described as black clay, claystone, or shale. However, detailed descriptions usually reveal interbeds of differing lithologies, usually green and black clays (or claystones or shales) with sharp contacts between interbeds.

The Lower Cretaceous black clay units are usually interpreted as representing bottom water stagnation (euxinic conditions) in a restricted early-Atlantic Ocean (e.g., Lancelot et al., 1972; Bolli, Ryan, et al., 1975; Perch-Nielson, Supko, et al., 1975). One of the problems of an euxinic basin interpretation is explaining the cyclic interbeds of green clay that are generally bioturbated and usually exhibit sharp contacts with overlying and underlying black clay units. Lancelot et al., (1972) interpret interbedding of green and black clay units at Sites 101 and 105 in the western Atlantic as the result of cyclic alternations of periods of stagnation, interrupted by periods of slow bottomcurrent circulation. A similar interpretation was proposed by Nesteroff (1973) for black "sapropels" interbedded with pelagic marls and oozes of Quaternary and Pliocene age in the Mediterranean Sea. $\mathrm{He}$ postulated that short periods of stagnation (black muds) began and ended suddenly and were separated by periods of resumed bottom circulation during which pelagic marls were deposited. Bolli, Ryan et al. (1975) conclude that black shale of Aptian to Albian age cored at Sites 361 and 364 in the Cape and Angola basins is indicative of totally stagnant euxinic conditions in these basins. All of these interpretations imply that rapid initiation and cessation of bottom-water circulation resulted in interbedding of organic-rich black muds, and less organic-rich bioturbated green muds or pelagic marls. These models also imply that the variability in organic content of the sediments is the result of degree of preservation of organic matter, and not necessarily in rate of organic production.

Alternatively, it is possible that the fluctuating organic content of the sediments is the result of variability in rate of supply of organic debris, either from changing productivity in surface waters or from pulsing of terrigenous organic matter. It is not difficult to visualize abrupt changes in bottom-water circulation in a restricted basin such as the Baltic, the Mediterranean Sea, or even the Early Cretaceous Atlantic Ocean, but it is difficult to imagine total stagnation for the Atlantic during Late Cretaceous and the Tertiary. In this regard, the section at Site 367 provides some valuable clues. Here, cycles of organic-rich and less organic-rich sediments continue at least into the Eocene. In fact, almost all of the section cored at Site 367, from Jurassic to Holocene, consists of cycles of organic material (see Dean et al., this volume). The cyclic alternations of black and green radiolarian clay of Eocene age have the same period and look similar to the alternations of black shale and green clay of the Lower Cretaceous. 


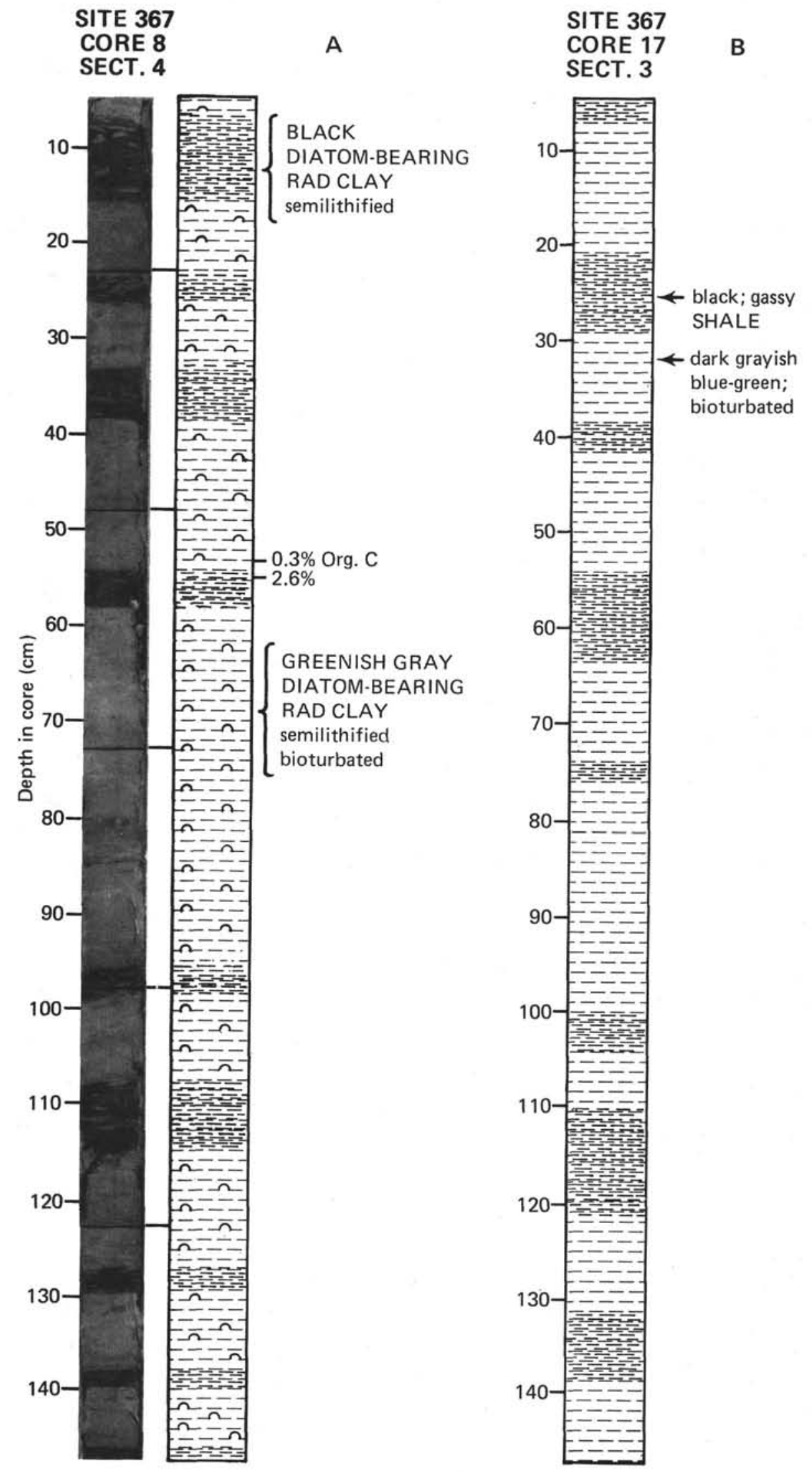

Figure 7. (A) Core photos and lithologic column of a section from Lithologic Unit 2 at Site 367. (B) Lithologic column of interbedded black shale and green clay at the transition between Lithologic Units 3 and $4 a$. 
We suggest that cylic variations in organic content at Site 367 , and probably at other sites in the Atlantic, may have been produced by variations in rate of supply of organic matter. It is not possible with the data available at this time to determine if variable organic supply was the result of variable planktonic productivity or to variable supply of terrigenous organic material from the African continent. Simoneit et al. (1972) found that the Lower Cretaceous black muds at Site 105 contain low amounts of solvent soluble organic material, which implies to them that the organic carbon consists of adsorbed and entrapped organic matter, and probably a significant amount of kerogen. We feel that much of the organic matter in Leg 41 sediments is land derived because the organicrich sediments contain palynomorphs and recognizable plant debris in addition to terrigenous clastic materials. We further believe that the mechanisms that resulted in variations in rate of supply of this organic matter are a response to long-term climatic changes (see Dean et al., this volume).

The sediments at Site 367 contain several short sections of cyclic alternations of red and green clay sandwiched between sections of green and black clay cycles. We interpret these cyclic-color alternations as being the result of variations in redox conditions within the sediments caused by variation in rate of organic decay. In other words, variations in redox conditions in the sediments are the result of variations in rate of organic supply. Our model can be visualized as reflecting a fluctuating boundary between oxidizing and reducing conditions in response to variations of input of organic matter (see Figure 8). If the rate of input of organic matter is greater than the rate of oxidation, then deoxygenation of bottom waters would occur for some distance above the sediment water interface and the boundary between oxidizing and reducing conditions would reside within the water column. If the rate of input equals the rate of oxidation then the bottom waters would be oxygenated and the oxidizing/reducing boundary would lie at or slightly below the sediment/water interface. If oxidation of organic matter is greater than input, then the bottom water and the upper portion of the sediment column will be oxygenated and the oxidizing/reducing boundary will reside within the sediment column. The laminated black shale with no signs of bioturbation represents the first case. The second situation would produce sediments similar to our bioturbated green clays. Bioturbated red clays would be the poduct of the third case. This is opposed to the total stagnation model in which the amount of organic material is a function mainly of the rate of input of oxygen by bottom-water advection.

\section{JURASSIC AND CRETACEOUS REGIONAL CORRELATIONS-SITE 367}

The Cretaceous and Jurassic sediments cored at Site 367 are remarkably similar to those cored at Sites 99 , 100,101 , and 105 in the western Atlantic on Leg 11. A detailed discussion of these similarities and correlations with the classic Tethyan Jurassic to Lower Cretaceous are discussed by Jansa et al. (this volume).
The interbedded light gray limestone and olive marlstone of Kimmeridgian to early Aptian age at Site 367 (lithologic Unit 5a) are equivalent to the upper Tithonian to Hauterivian nannofossil chalk and organic-rich marl at Sites 101 and 105 of DSDP Leg 11 (Hollister, Ewing, et al., 1972). These are considered to be equivalent to the Maiolica and the Marne a Fucoidi facies of the Tethyan sections (see Bernoulli, 1972; Jansa et al., this volume).

The striking red and gray nodular limestones of late Jurassic age at Site 367 (lithologic Unit 6) are virtually identical to the red and white nodular limestones cored at Sites 99, 100, and 105 in the western Atlantic (Hollister, Ewing, et al., 1972). These units have been correlated with the classic Ammonitico Rosso facies (Bernoulli, 1972; Bernoulli and Jenkyns, 1975), and the Rosso and Aptici facies (Jansa et al., this volume) of the Tethyan region.

A surprisingly good correlation exists between the section at Site 367 and the Lower Cretaceous to Upper Jurassic section exposed on Maio Island in the Cape Verde Islands (Stahlecker, 1934). The time-equivalent section at Maio Island differs mainly by being at least two to three times thicker than at Site 367. This difference may result from the Maio Island section having been deposited in somewhat shallower water (Jansa et al., this volume).

\section{UNANSWERED QUESTIONS}

Several of the sites drilled during Leg 41 provide puzzling discoveries in the recorded sediments. Here, we pose the questions in terms of the observations and give a few tentative conclusions.

\section{Coarse Clastics at Site 370}

The cores recovered at Site 370 contain a surprising amount of coarse-clastic sediments throughout the entire section. This site has periodically been under the influence of coarse-clastic terrigenous deposition from at least the Barremian to the Pleistocene. Grain size distribution, bed contacts, and sedimentary structures all suggest that a number of dynamic processes were active at Site 370 . The section from the Neogene to the upper Neocomian (Cores 2 to 40 ) has graded beds with sharp lower contacts and gradational upper contacts. These beds are turbidites and reflect gravity flows from upslope regions with little or no subsequent reworking. The lower Neocomian (Cores 41 to 51 ) clastic beds have no apparent grading, have sharp upper and lower contacts, are laminated, and contain low-angle cross bedding, current ripples, slump structures, and concentrations of plant debris, mica, or heavy minerals on bedding planes. These sediments may have been deposited by gravity flows, but show a significant amount of reworking.

The composition of the sediments suggests that the depositional environment was one or a series of submarine fans. The wide variety of clast composition, everything from oolites and coarse quartz grains to planktonic forams (see Site Chapter 370), suggests that the source areas for the sediments encompass a range from subaerial landmass, to shelf carbonates, to the pelagic realm. 


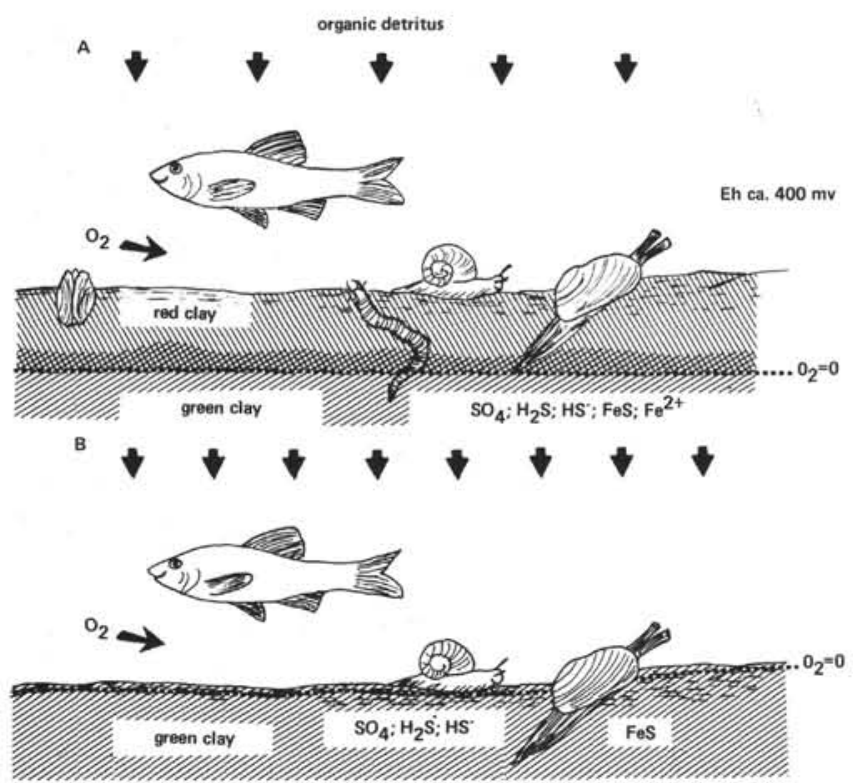

c

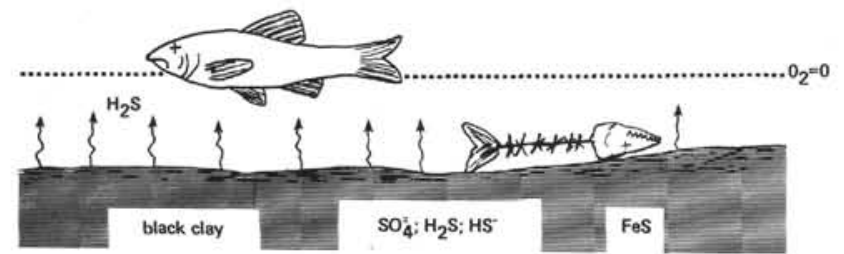

Figure 8. Variations in rate of organic decay and the position of the boundary between oxidizing and reducing conditions $\left(\mathrm{O}_{2}=0\right.$ isopleth) with variations in the rate of influx of organic detritus in deep-sea environments. Case A - Low rate of supply of organic detritus (black arrows) so the $\mathrm{O}_{2}=0$ isopleth would be some distance below the sediment-water interface (i.e. surface sediments and bottom waters oxidized). The bottom waters would be well oxygenated. Most organic matter would be consumed in the water column or at the sediment-water interface by aerobic metabolism $\left(\mathrm{CH}_{2} \mathrm{O}+\mathrm{O}_{2}=\mathrm{CO}_{2}+\mathrm{H}_{2} \mathrm{O}\right)$. The surface sediments would be highly oxidized (Eh $>400$ mv, Bass Becking et al., 1960). Iron would be present mainly as ferric oxides and hydroxides, sulfur would be present mainly as $\mathrm{SO}_{4}{ }^{2-}$, and the red color would be due to ferric oxides and hydroxides. Example: deep-sea red clay environments which has a relatively high rate of organic supply and a very slow rate of sedimentation. Case B - Moderate rate of supply of organic detritus so that the $\mathrm{O}_{2}=0$ isopleth would be at or near the sediment-water interface (i.e. surface sediments reduced, bottom waters oxidized). The bottom waters would usually be well oxygenated. The faster rate of supply of organic detritus, or more rapid burial of the organic detritus would allow an abundant supply of organic matter to exist in the sediments after burial. The first phase of diagenetic organic decomposition is aerobic metabolism followed by anaerobic bacterial sulfate reduction $|2| \mathrm{CH}_{2} \mathrm{O}$ $+\mathrm{SO}_{4}{ }^{-}=2 \mathrm{HCO}_{3}^{-}+\mathrm{H}_{2} \mathrm{~S}$ and $2 \mathrm{CH}_{2} \mathrm{O}+\mathrm{SO}_{4}{ }^{2-}=\mathrm{HCO}_{3}^{-}$ $+\mathrm{HS}^{-}+\mathrm{CO}_{2}+\mathrm{H}_{2} \mathrm{O}$ ). Additional reduction may be accomplished by reduction of nitrate to nitrite and/or ni- trogen $\left(\mathrm{CH}_{2} \mathrm{O}+2 \mathrm{NO}_{3}^{-}=\mathrm{CO}_{2}+2 \mathrm{NO}_{2}^{-}+\mathrm{H}_{2} \mathrm{O} ; 3 \mathrm{CH}_{2} \mathrm{O}\right.$ $\left.+4 \mathrm{NO}_{2}=2 \mathrm{~N}_{2}+\mathrm{CO}_{2}+2 \mathrm{CO}_{3}=+3 \mathrm{H}_{2} \mathrm{O}\right)$. The surface sediments would be reduced $(E h<0)$, the benthonic epifauna would be present, and benthonic infauna may or may not be present (depending upon oxygen conditions in the sediments and oxygen requirements of individual organisms). Iron would be present as $\mathrm{Fe}^{2+}$ as well as some ferrous sulfide (FeS), sulfur would be present as $\mathrm{SO}_{4}{ }^{2-}$, $\mathrm{H}_{2} \mathrm{~S}, \mathrm{HS}^{-}$, and $\mathrm{FeS}$, and the green color (usually various shades of greenish gray or olive) would be due to reduced iron and the presence of organic matter. Example: This is the most common situation in an open-circulation marine environment (Krumbein and Garrels, 1952; Bass Becking et al., 1960). Case C - Rapid rate of supply of organic detritus so that the $\mathrm{O}_{2}=0$ isopleth would be some distance above the sediment-water interface (i.e., surface sediments highly reduced, bottom waters anoxic with $\mathrm{H}_{2} \mathrm{~S}$ present). The extent of deoxygenation of bottom waters would be controlled by rate of oxygen consumption, rate of $\mathrm{H}_{2} \mathrm{~S}$ production, rate of oxygen supply to the bottom waters, strength of bottom currents, and rate of sedimentation. A high rate of supply of organic detritus occurs (sediments commonly contain up to 10\% (or more) dry weight organic matter), and organic decomposition would occur mainly by anaerobic bacterial sulfate reduction, possibly aided by reduction of nitrate. Production of $\mathrm{H}_{2} \mathrm{~S}$ would be fast enough, relative to rate of oxygen supply and/or rate of $\mathrm{H}_{2} \mathrm{~S}$ removal by bottom currents, to allow $\mathrm{H}_{2} \mathrm{~S}$ to accumulate in the bottom waters. The accumulation of $\mathrm{H}_{2} \mathrm{~S}$ would be aided by restricted circulation, but the primary cau se of anoxic conditions would be a high biological oxygen demand. The surface sediments would be highly reduced (Eh ca. -400 $m v)$, iron would be present mainly as ferrous sulfides (plus some $\mathrm{Fe}^{2+}$ ), sulfur would be present as $\mathrm{SO}_{4}{ }^{2-}$, $\mathrm{H}_{2} \mathrm{~S}, \mathrm{HS}^{-}$, and $\mathrm{FeS}$, and tive benthonic epi- and in-faunas would be eliminated. The black color would be due mainly to organic matter and $\mathrm{FeS}$ (mackinawite). The FeS would eventually be converted to $\mathrm{FeS}_{2}$ (pyrite or marcasite) which would tend to lighten the color of the sediment. However, maturation of the organic matter would tend to darken the color of the sediment with the result that black muds would probably become black shales through diagenesis although the FeS had been converted to $\mathrm{FeS}_{2}$. If initial deposition resulted in the intercalation of organic-rich and/less organic-rich layers in a sediment which is otherwise homogeneous, then migration of $\mathrm{Fe}$ and $\mathrm{SO}_{4}{ }^{2-}$ into the more organic-rich layers may produce localized concentrations of $\mathrm{FeS}$ and an intensification of color differences (Berner, 1969). Example: The so-called euxinic environments. These are usually found close to land because of the need for high organic influx, either from a high rate of autoch thonous plankton productivity or a large influx of allochthonous terrigenous organic material. Anoxic conditions in both the sediments and bottom waters would be caused by high oxygen demand, but restricted bottom water circulation may be required for complete deoxygenation of the bottom waters and the accumulation of $\mathrm{H}_{2} \mathrm{~S}$. Under extreme conditions of biological oxygen demand, deoxygenation of bottom waters could occur without reduced bottom water circu- 
lation. The Southern California coastal basins and Walvis Bay (west African continental shelf) have sediments with Eh values around $-400 \mathrm{mv}$ and organic contents in excess of $10 \%$ dry weight; $\mathrm{H}_{2} \mathrm{~S}$ accumulates in Walvis Bay but not in the Southern California basins, the difference presumably due to greater restriction in Walvis Bay.

We lean toward a submarine fan interpretation for these sediments but it is impossible to get a feel for the geometry of a deposit from a 6 -cm diameter core. If these sediments do represent a submarine fan, then we are struck by the lack of significant channels. However, this apparent lack of channels might be accounted for by the following factors:

1) The fan has only a few major channels and Site 370 is located in the region of the fan away from those channels. The sediments recovered would then represent a combination of overbank clays and thin silt beds or minor turbidites deposited from turbulent flows that were not directed to the main channels.

2) The channels were very shallow (not deeper than several tens of centimeters to one meter and the depositional area had the physiographic appearance of a braided plain, with temporary channels migrating across the fan area, perhaps as sheet flow.

3) Possibly we are not dealing with a submarine fan but rather a continental rise with no major canyon system. Perhaps all we are seeing is the interplay between geostrophic-current winnowing, gravity flows, and pelagic deposition.

\section{Unconformities at Sites 369 and 370}

Major unconformities at Sites 369 and 370 have remarkably similar sediment above and below the unconformities. The unconformity at Site 369 has a hiatus of ca. 20 m.y. with light gray to light greenish gray argillaceous nannofossil limestone with porcellanite, chert, and pyrite of middle Eocene age that directly overlie bluish white to greenish gray argillaceous nannofossil limestone with porcellanite, chert, and pyrite of Maestrichtian age. Although the sediments on either side of the unconformity are virtually identical, it is curious that the unconformity occurs in the middle of a thin (ca. $30 \mathrm{~m}$ ) limestone unit that is sandwiched between two nannofossil units (see above discussion on diagenesis). We cannot help but speculate that lithification of the marls may be in some way related to the presence of a $20-m . y$. hiatus. Other time gaps occur within the section at Site 369, but they are either very minor or are associated with slumps.

The major unconformity at Site 370 is even more profound with a hiatus of about $35 \mathrm{~m} . \mathrm{y}$. The sediments above and below the unconformity are remarkably similar in composition, indicating almost no change in depositional conditions; they differ only slightly in degree of induration. The sediments above the unconformity consist of dark greenish gray nannofossilbearing clay with minor interbedded nannofossil marl. The sediments below the unconformity, which are 35 m.y. older, consist of dark greenish gray nannofossilbearing claystone with minor interbeds of argillaceous limestone. The physical properties indicate only an increase in the rate of induration (loss of porosity) below the unconformity but right at the hiatus even the physical properties are identical (see Site 370 Chapter).

The similarity of the sediments above and below the unconformity and the greater degree of induration below the unconformity suggest erosion rather than nondeposition was the cause of the missing section. Further, the 35 m.y. gap and additional 100 m.y. record of identical facies indicates a stable environment at the base of the continental slope that persisted for at least 135 m.y. (at least Berriasian to Pleistocene).

\section{Pelagic Facies at Site 369}

The section cored at Site 369 is predominantly pelagic with only a very minor contribution of terrigenous sediment. The site is located on the continental slope off Spanish Sahara so we expected to recover mainly hemiplagic facies. The clays, which are abundant, may represent a terrigenous fraction, but we expected more clay and coarser material to have diluted the biogenic components. The only other DSDP site on a continental slope, Site 108, Leg 11, found no terrigenous components although only two cores were recovered at this site, both containing sediments limited to Eocene age.

Tentatively, we can think of three explanations for this general lack of terrigenous material. (1) The coarse material could have been confined to extensive submarine canyon systems and therefore bypassed the continental slope. The present continental margin off northeast Africa has such a system (Seibold and Hinz, 1974), and canyon systems may have existed throughout the Cretaceous and Tertiary. (2) Possibly not much coarse debris was shed off northwest Africa during the Cretaceous and Tertiary, possibly because the region was predominantly arid during this interval, as it is today. (3) Coarse clastics may have been trapped in the marginal Tarfaya Basin, and only fine terrigenous components were transported to the continental slope.

If the third hypothesis is valid, then it provides a critical insight into the hydrocarbon reservoir potential of continental slope deposits seaward of shelf basins. It has been proposed that continental slopes contain hydrocarbons reservoirs in sand and silt lenses (Beck and Lehner, 1974). Our findings on the continental slope seaward of the Tarfaya Basin do not agree with this general hypothesis, but rather show that a continental slope seaward of a coastal basin can lack coarse-terrigenous beds.

\section{Volcanic Ash Recovered at Sites 368 and 369}

Sites 368 and 369 are located within a predominantly volcanic province that encompasses western Senegal, the Cape Verde Islands, and the Canary Islands. We anticipated finding considerable volcanic ash in the Tertiary sections. Cores from these two sites did contain major beds of volcanic ash but they were rare and thin. Disseminated ash occurred over a longer sequence, but at both sites the discrete ash beds are restricted to the middle Miocene. The middle Miocene occurrences correlate with the age of diabase intrusions at Site 368 (Duncan and Dalrymple, this volume); the age of major volcanism around Dakar, Senegal (Furon, 1963); Canary Island volcanism 
(Furon, 1963; Dillon and Sougy, 1974; Grunau, et al., 1975); and Cape Verde Island volcanism (Furon, 1963; Mitchell-Thome, 1974; Grunau et al., 1975). We are surprised to find so few volcanic ash beds in the Miocene with all this volcanic activity. A further surprise is the lack of evidence at Site 369 for the Pliocene volcanic eruptions that formed the plateau basalts of the Canary Islands.

We have only uncovered the surface of interesting problems and puzzling relationships which occur in the sediments we recovered on Leg 41 . The wide diversity of lithofacies and the different physiographic provinces drilled should be synthesized with the data appearing or that will appear shortly in DSDP Legs $11,14,39,40$, 43,44 , and additional IPOD legs. Certainly these data will provide insight into the development of Atlantictype passive continental margins. We hope that many of our interpretations and conclusions will be challenged, and certainly they will be modified as results from later DSDP legs and detailed studies of Leg 41 materials are published.

\section{REFERENCES}

Baas-Becking, L.G.M., Kaplan, I.R., and Moore, D., 1960. Limits of the natural environment in terms of $\mathrm{pH}$ and oxidation-reduction potentials: J. Geol., v. 68 , p. 243284.

Beck, R.H. and Lehner, P., 1974. Oceans, new frontier in exploration: Am. Assoc. Petrol. Geol., v. 58, p. 376-395.

Berner, R.A., 1969. Migration of iron and sulfur within anaerobic sediments during early diagenesis: Am. J. Sci., v. 267 , p. $19-42$.

Bernoulli, D., 1972. North Atlantic and Mediterranean Mesozoic facies: A comparison. In Hollister, C.D., Ewing, J.I., et al., Initial Reports of the Deep Sea Drilling Project, Volume 11: Washington (U.S. Government Printing Office), p. 801-871.

Bernoulli, D. and Jenkyns, H. C., 1975. Alpine, Mediterranean and Central Atlantic Mesozoic facies in relation to the early evolution of the Tethys. In Dott, R.H., Jr., and Shaver, R.H. (Eds.), Modern and ancient geosynclinal sedimentation: Soc. Econ. Paleontol. Mineral., Spec. Pub. 19, p. 129-160.

Bolli, H. M., Ryan, W. B. F., et al., 1975. Basins and margins of the eastern South Atlantic: Geotimes, v. 20, p. $22-24$.

Broecker, W. S. and van Donk, J., 1970. Insolation changes, ice volumes, and the $\mathrm{O}^{18}$ record in deep-sea cores: Rev. Geophys. Space Phys., v. 8, p. 169-198.
Dillon, W. P. and Sougy, J. M. A., 1974. Geology of west Africa and Canary and Cape Verde Islands In Nairn, A. E. M. and Stehli, F. G. (Eds.), The ocean basins and margins, v. 2: New York (Plenum Press), p. 315-390.

Furon, R., 1963. Geology of Africa: New York (Hafner Publ. Co.).

Grunau, H. R., Lehner, P., Cleintuar, M. R., Allenbach, P., and Bakker, G., 1975. New radiometric ages and seismic data from Fuerteventura (Canary Islands), Maio (Cape Verde Islands) and Sao Tome (Gulf of Guinea). In Progress in Geodynamics, Royal Netherlands: Amsterdam (Academy of Arts and Sciences), p. 90-118.

Hollister, C. D., Ewing, J. I., et al., 1972. Initial Reports of the Deep Sea Drilling Project, Volume 11: Washington (U.S. Government Printing Office).

Krumbein, W.C. and Garrels, R.M., 1952. Origin and classification of chemical sediments in terms of $p \mathrm{H}$ and oxidation-reduction potentials: J. Geol., v. 60 , p. 1-32.

Lancelot, Y., Hathaway, J.C., and Hollister, C.D., 1972. Lithology of sediments from the western North Atlantic, Leg 11, Deep Sea Drilling Project. In Hollister, C.D., Ewing, J.I., et al., Initial Reports of the Deep Sea Drilling Project, Volume 11: Washington (U.S. Government Printing Office), p. 901-950.

Milankovitch, M., 1938. Die chronologie des Pleistocans: Acad. Sci. Math. Nat. Belgrade. Bull., v. 4, p. 48.

Mitchell-Thome, R.C., 1974. Sedimentary rocks of Macronesia: Geol. Rundschau, v. 63, p. 1179-1216.

Nesteroff, W.D., 1973. Petrology and minerology of Sapropels. In Ryan, W.B.F. and Hsü, K.J., et al., Initial Reports of the Deep Sea Drilling Project, Volume 13: Washington (U.S. Government Printing Office), p. 713720.

Perch-Nielson, K., Supko, P.R., et al., 1975. Leg 39 examines facies changes in South Atlantic: Geotimes, v. 20, p. 2628.

Schlanger, S.O. and Douglas, R.G., 1974. Pelagic ooze-chalklimestone transition and its implication for marine stratigraphy. In Hsü, K.J. and Jenkyns, H.C. (Eds.), Pelagic sediments: On land and under the sea: Intern. Assoc. Sedimentol. Spec. Publ. No. 1, p. 117-148.

Seibold, E. and Hinz, K., 1974. Continental slope construction and destruction, west Africa. In Burk, C.A. and Drake, C.L. (Eds.), The geology of continental margins: New York (Springer Verlag) p. 179-196.

Simoneit, B.R., Scott, E.S., Howells, W.G., and Burlingame, A.L., 1972. Preliminary organic analysis of the Deep Sea Drilling Project cores, Leg 11. In Hollister, C.D., Ewing, J.I., et al., Initial Reports of the Deep Sea Drilling Project, Volume 11: Washington (U.S. Government Printing Office), p. 1013-1046.

Stahlecker, R., 1934. Neocom auf der Kapverden-Insel Maio: Neues Jahrbuch für Mineralogie, Beil.-Bd., v. 73, p. 265301 . 